\title{
APPLICATION OF FTA AND FMEA METHOD TO IMPROVE SUGAR PRODUCTION PROCESS QUALITY
}

\author{
JojoAndriana, Sunday Alexander Theophilus Noya \\ Industrial Engineering Study Program \\ Machung University Malang \\ Jl.VillaPuncakTidar N.01 Malang \\ 411110012@student.machung.ac.id, sunday.alexander@machung.ac.id
}

\begin{abstract}
Defective product is a product that has poor quality and do not meet the standart. This defective products can give a bad impact to company, such as high production costs and decreased image company. Several methods that can be used to improve the quality is Six Sigma DMAIC methodology, FTA, and FMEA method. This study is conducted for several purpose, they are to determine the value of sigma level on the process of sugar production in PT.PG. Krebet Baru, to determine the factors that cause defective products in the process of sugar production by the FTA method, and to make a suitable solution based on the FMEA defective causes. The process sigma level in PT.PG.Krebet Baru is 3.58. That value sigma level indicates PT. PG. Krebet Baru is a company that are still growing and need improvement. The primary cause of the defects in the production process is a factor of operator and machine. Mode of failure with the highest RPN at 210 is time for steam process is too long, so they need to install the equipment that can detect the water level on sugar. When this equipment is installed, the exact time for drying will be known and the amount of defective product will be decreased.
\end{abstract}

Keywords : Defective Product, Six Sigma, DMAIC, FTA, FMEA.

\section{INTRODUCTION}

Today, quality is an important thing for a company to compete in the fierce market competition. That is because customers have realized that quality needs to be taken into consideration when selecting an item or service. Therefore, the companies need to implement a system that can control quality and improve it continuously. So that the product will always meet the standards and spesification.

Defective products are discrepancies or errors in the product received by consumers (Evans and Lindsay, 2008). This defective product can give a bad impact to company, such as high production costs and decreased image company. The more number of defects which is produced in process production, the higher cost of quality in rework and inspection measures will be. Defective product will also give bad impact for the image of the company. The more number of defective products, the image of the company get the worse in consumers' view. So that the consumers will not give their loyality to the company.

PT. PG. KrebetBaru is a company that runs in agro-industry. PT. PG. KrebetBaru is the part of PG Rajawali I. This company uses sugarcane for raw material in production process. The output of that process is white crystal sugar and the side product is molasses. PT. PG. KrebetBaru has a commitment to develop its products in order to keep high quality. Because the quality of white crystals sugar is one of the factors that influences people's interest in buying the product. Therefore, PT. PG. KrebetBaru implements high quality standart on the production activities and has controled their quality product and process, so that the number of defective products can be minimized. However, PT.PG.KrebetBarucan not still achieve zero defect.

There are three types of defective product in the process of sugar production in PT. PG. KrebetBaru, they are wet sugar crystal, nonstandart crystal grains which it is called gravel sugar, and nonstandart sugar color. Although the number of defective products produced are still under the maximum limit, PT.PG KrebetBaru still needs to rework the defective product. This rework process gives a bad impact on production, it makes the cost 
of production get higher. The table below is the data about the number of defects in PT. PG. New Krebet on 1 July until 20 November 2014:

Table 1. The Number of Defects on 1 July Until 20 November 2014

\begin{tabular}{|l|r|r|}
\hline \multicolumn{1}{|c|}{ Month } & $\begin{array}{c}\text { Wet Sugar } \\
\text { (Kuintal) }\end{array}$ & $\begin{array}{c}\text { Gravel Sugar dan non } \\
\text { standart color (Kuintal ) }\end{array}$ \\
\hline July & 0 & 5965 \\
\hline August & 857 & 7580 \\
\hline September & 0 & 8342 \\
\hline October & 0 & 8516 \\
\hline November & 1344 & 5879 \\
\hline
\end{tabular}

Based on the data above, PT. PG. KrebetBaru need to do the proper supervision and control of the production process in order to produce crystal sugar in good quality. The purpose of this study was to determine the factors that cause defective products using Fault Tree Analysis (FTA), and provide appropriate recommendation to the PT. PG KrebetBaru to minimize the product defects by using Failure Mode and Effect Analysis (FMEA). This study is expected to decrease the number of defective products in the production and the company can minimize the production costs (rework).

\section{THEORY FOUNDATION}

\section{A. Quality}

The quality can be interpreted with various meanings that have been widely expressed by some experts. According to Deming (1986, in Mulia, 2011) quality is a level of uniformity that can be predicted at a low cost and related to market. Edward Deming assumes that the quality of the product attributes include conformity with the demands of consumers, but the quality should be more than that the demand. According to Juran (1989, in Mulia, 2011) the quality is a suitability of the use (fitness for use), in which a product or service needs to adjust with users' needs and expectations. Goetsch and Davis (2006) also suggest that the definition of the quality is a condition associated with the products, services, people, processes and environments that meet or exceed the expectations.

From the definition given by experts in the field of quality, there is no standart meaning of quality. But there are similarities in the following elements, such as the quality of the business meet or exceed customer expectations, quality may include products, services, people, processes and the environment, and the quality is dynamic, it can change and depend on consumers' needs in the future (Tjiptono, 2000).

\section{B. Dimension of Quality}

Quality has several dimensions that can apply to manufacturing companies. Garvin (1987, in Goetsch and Davis, 2006) developed the eight dimensions of quality that can be used as a basis for strategic planning and analysis of product manufacturing. The first dimension is the performance, which is the principal operating characteristics of the core product. The second dimension is the characteristics or additional privileges (features), which is characteristic of secondary. The third dimension is the reliability, which is less likely to be damaged. The fourth dimension is conformance to specification, which is characteristics of design and operations that meet the standards that have been set previously.

The fifth dimension is the durability, which related to how long the product can be used continously. The sixth dimension is serviceability, which is including speed, competence, convenience, easily repaired and complaint handling problems 
satisfactorily. The seventh dimension is an aesthetic, which the product appeals that attract the senses of consumers. The eighth dimension quality is perceived quality, which the image and reputation of the product on the company's responsibilities (Goetsch and Davis, 2006).

\section{Defective Product}

According to Evans and Lindsay (2008), defective products are nonconformance or errors in the product received by consumers. In other words, a defective product is a bad product that be given to customers because of the low product quality and it will give disadvantages to the consumer.

\section{Six Sigma}

According Gaspersz (2005), six sigma is a method or technique of control and improve the quality which is a dramatic new breakthrough in the field of quality management. There is way to measure the value of six sigma, there are two measuring tools were used, that is DPMO (Defect Per Million Opportunities) and sigma level. Here is the formula for the calculation of DPMO:

$$
D P M O=\frac{\left(\frac{\text { Total Defect }}{\text { Total Production }}\right) \times 1.000 .000}{\text { Defect Probability }}
$$

After DPMO value have been known, then it can be determined categories of the company. Here are the categories of companies according to the value of DPMO and Sigma level (Gaspersz, 2006):

Table 2. Categories of Company According to Value DPMO and Sigma Level

\begin{tabular}{|c|l|c|}
\hline DPMO & \multicolumn{1}{|c|}{ Category } & Sigma Level \\
\hline 691.462 & $\begin{array}{l}\text { The company is not competitive. The quality of } \\
\text { product is not good. The company will suffer a loss } \\
\text { due to smaller revenues than costs. }\end{array}$ & 1 \\
\hline 308.538 & The average industry in Indonesia & 2 \\
\hline 66.807 & $\begin{array}{l}\text { Companies can compete, in this case That } \\
\text { companies are still growing. }\end{array}$ & 3 \\
\hline 6.210 & \begin{tabular}{l} 
The average industry in America \\
\hline 233
\end{tabular} & $\begin{array}{l}\text { The companies is large companies that produce } \\
\text { high quality products and can compete in the world } \\
\text { of international }\end{array}$ \\
\hline 3.4 & \begin{tabular}{l} 
Industry worldwide \\
\hline
\end{tabular} \\
\hline
\end{tabular}

\section{E. Fault Tree Analysis (FTA)}

Fault Tree Analysis (FTA) is an analytical technique fault tree with form that can be used to analyze the root cause of the problem (Nugroho, et al, 2011). According to Vesely (2002) FTA method has steps that need to be done, the first steps is identify the object. The second is to determine top event or the main problem of the fault tree. The third is to establish the boundaries of the FTA. The fourth step is studying the the system to know how the elements related to one another and with the top events. The fifth step is to make fault tree starting from the top events then link towards the bottom. Then the sixth step is to analyze the fault tree qualitatively by determining the cut set of FTA. The last step in the FTA is preparing a corrective action plan to prevent failure. 


\section{F. Failure Mode and Effect Analysis (FMEA)}

FMEA is a methodology which is designed to identify potential failure modes of a product or process before they happen. It considering the risks that associated with those failure modes, identify and implement corrective actions to resolve most important problems (Reliability, 2002).

There is some basic steps in Failure Mode and Effect Analysis (FMEA) method. The first step is to identify the function of the production process. The second step is to identify potential failure modes of production process. Then the third step is to identify the potential effects of production failures. The fourth step is to identify potential causes of failure of the production process. The fifth step is to identify the modes of detection of the production process. The sixth step is to determine the rating of the severity, occurance, detection, and the RPN of production process. The last step is to make the recommendation (Villacourt, 1992).

The final outcome of FMEA method is a Risk Priority Number (RPN). RPN is a critical indicator to determine the appropriate corrective actions for each failure modes. RPN is used to estimate the the risk. There are three criteria for calculating the RPN, there are severity, occurance, and detection. Severity (S) is how serious the effects caused the process. Occurance $(\mathrm{O})$ is how often the cause of events occurred in process. Detection (D) is how the failure can be detected before it reaches the customer (Villacourt, 1992).

\section{RESEARCH METHODOLOGY}

The first step of this study is observation in the sugar production process PT. PG. Krebet Baru Malang. In this study, there are two datas were used, there are primary data and secondary data. Primary data was obtained from field studies. Methods for obtaining primary data is by doing an interview with supervisors at every stage of the production process, direct observation to the production process, and form FMEA assessment rating. The information abou the causes of defective products and the other things that need to avoid the occurrence of defective products are got by conducting the interview. Method of giving form assessment is to assess the level of severity, occurance, and detection on any failure of the production process. The FMEA form is filled out by supervisors that have been experienced in their fields. The secondary data is obtained by reading the existing data on the production. Secondary data were obtained include data on the number of defects in each shift, data on the number of production and product specification data. That data will be used in the measure phase.

The next step in this study is the DMAIC (Define, Measure, Analyze, Improve, and Control). In the define phase will be targeting the problem by described the production process. In the define phase will also determine the purpose of improvement. In the measure phase will be calculated DPMO and sigma level on the production process in PT. PG. KrebetBaru. This measure phase is using secondary data which obtained from production data of PT. PG. KrebetBaru. In the analyze phase will be analysis the factors that cause product defects. In this analyze phase will use the FTA method. In the improve phase will be giving recommendations for improvement for each failure mode. Improvement recommendations are arranged by the results of the highest RPN to the lowest RPN. In the improve phase is used FMEA method. In the control phase will be considered the result of the improvement recommendations. The next step is predict new RPN which is based on interviews to the experts in the production process.

\section{RESULT AND DISCUSSION}

\section{A. Define Phase}

Define phase is the first step of the six-sigma DMAIC were aims to find out the existing problems, to define the scope of PT. PG. KrebetBaru, to determining the target problem, and to determine the purpose of the improvement. From the early 
observation, the problems that occur in the crystal sugar production process is the existence of defective products. The kind of defective product are wet sugar, gravel sugar, and non standart sugar color.

In this phase, define the scope will help to determine the stakeholders were would receive the impact of the improvement. A tools that were used in defining the scope is SIPOC diagram (Supplier-Input-Process-Output-Customer). The following is a diagram SIPOC for crystal sugar production process in PT. New PG.Krebet KB1:

Table 3. Diagram SIPOC in PT. PG. Krebet KB 1

\begin{tabular}{|c|c|c|c|c|c|}
\hline Suppliers & Inputs & Process & Outputs & Customer & Requirement \\
\hline $\begin{array}{l}\text { - } \begin{array}{l}\text { Sugarcane } \\
\text { department } \\
\text { (owend by }\end{array} \\
\text { PT. PG. } \\
\text { Krebet } \\
\text { Baru) } \\
\text { - Suppliers of } \\
\text { sugarcane } \\
\text { (from } \\
\text { sugarcane } \\
\text { farmers) } \\
\text { - Supplier of } \\
\text { calcium and } \\
\text { suphur }\end{array}$ & $\begin{array}{ll}- & \text { sugar } \\
& \text { cane } \\
\text { - } & \text { Steam } \\
\text { - } & \text { Water } \\
& \text { Imbib } \\
& \text { ition }\end{array}$ & 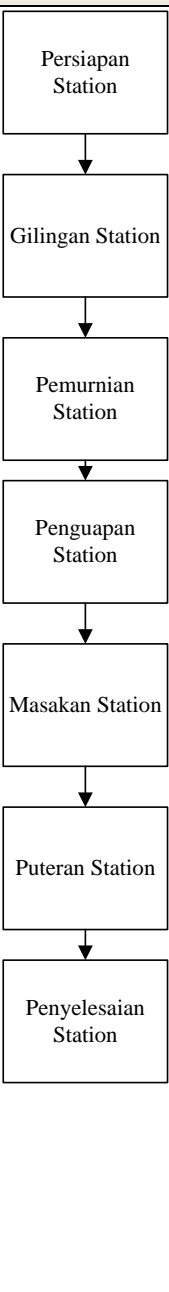 & $\begin{array}{ll}\text { White } \\
\text { crystal } \\
\text { sugar } \\
\text { product } \\
\text { SHS I } \\
\text { - } & \text { mollases } \\
\text { - } & \text { Dregs } \\
\text { - } & \text { Filter } \\
\text { cakes } \\
\text { (Blotong) }\end{array}$ & 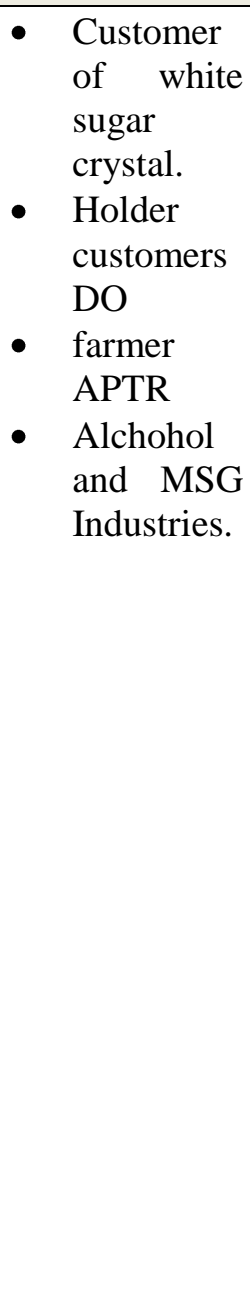 & 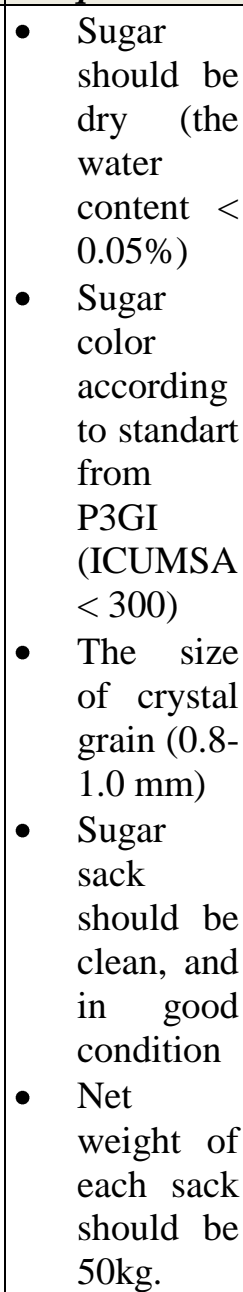 \\
\hline
\end{tabular}

At this define phase, the problem target and the purpose of this research will also be determine. In this study, the problem target is the existence of defective product from the sugar production process in PT. PG. New Krebet. The kind of defective products are sugar gravel, wet sugar, and non-standard sugar color. The existence of a defective product sue PT. PG. KrebetBaru to do reprocessing (rework). So that it make production costs higher. Improvement with six sigma DMAIC aims to minimize the number of defective product which is produced.

\section{B. Measure Phase}

Measure phase is the second step in six sigma DMAIC which aims to calculate the work baseline PT.PG. New Krebet. Calculate the work baseline will use parameter defect per million opportunity (DPMO) and the achievement of sigma level of the 
production process in PT. PG. KrebetBaru. The data were used in this phase is the data number of defects during the month of July 2014 until November 2014 and the data amount of white crystal sugar production were can be seen in the table below.

Table 4. Data Amount of White Chrystal Sugar Production on July-November 2014

\begin{tabular}{|c|c|}
\hline Month & Amount of Sugar Production (Kw) \\
\hline July & 119307 \\
\hline August & 135318 \\
\hline September & 166830 \\
\hline October & 170328 \\
\hline November & 92034 \\
\hline TOTAL & $\mathbf{6 8 3 8 1 7}$ \\
\hline
\end{tabular}

Based on the data above, DPMO can be calculated using the formula 2.1. Here's a DPMO calculation:

$$
D P M O=\frac{\left(\frac{38.483}{683.817}\right) \times 1.000 .000}{3}=18.758,91747
$$

Based on the DPMO calculation, the value of the defect per million opportunity (DPMO) is 18758.91747. So that the value of the sigma level can be determined by using a conversion table.The value of sigma level at PT.PG.KrebetBaru is 3.58. Based on the category of companies according to DPMO and sigma level in Table 2, the value of sigma level indicates that PT. PG. KrebetBaru is a growing company and still able to compete with other industries. Based on the value of sigma level is also indicates that the baseline of PT. PG. KrebetBaru is quite good, but it still requires improvements in the quality of production process.

\section{Analyze Phase}

Analyze phase is the third step in the series of six sigma DMAIC. At this phase, problem analysis was conducted by using Fault Tree Analysis (FTA). Based on the define phase, the process of crystal sugar production in PT.PG. KrebetBaru produce defective products in the form of wet sugar, gravel sugar, and nostandar sugar color. Therefore, this study has been established three top events which used as boundary problem on the crystal sugar production process systems. 
The result of FTA model is an illustration of brainstorming from experts which really know the process of crystal sugar production at PT. PG. New Krebet, they are Mr. Edy Kismanto as supervisor in manufacturing KB1 and Mr. Sujarwo as supervisor in round station KB1. FTA model for the occurrence of wet sugar can be seen in Figure 1, the gravel sugar can be seen in Figure 2, and the color of sugar is no standard can be seen in Figure 3. The following is the FTA model:

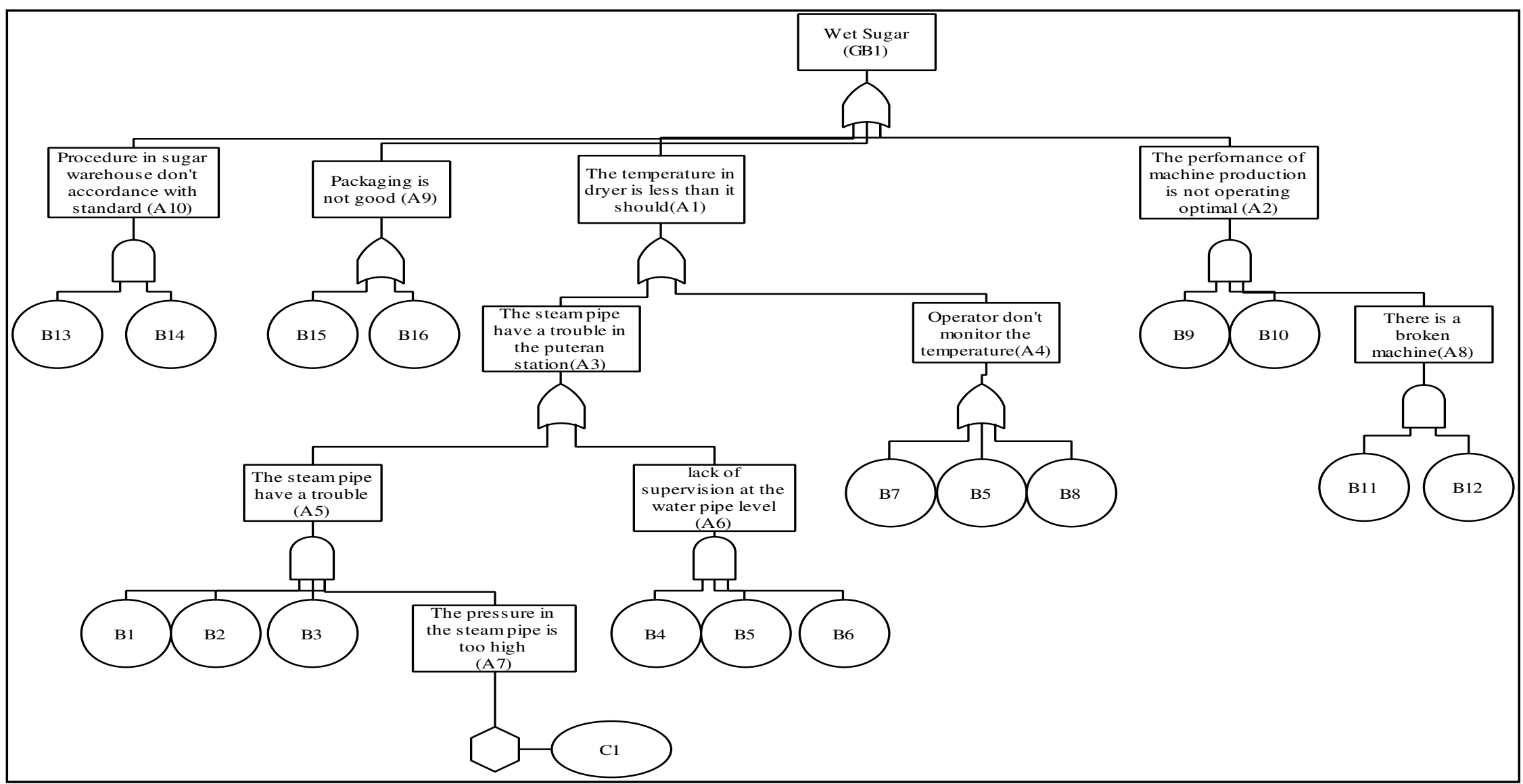

Figure 1. FTA Model For Wet Sugar 
The following are the symbols'explanation on the basic causes of the FTA model for gravel sugar:

Table 6. The Symbols' Explanation for Gravel Sugar

\begin{tabular}{|c|l|}
\hline Code & \multicolumn{1}{c|}{ Explanation } \\
\hline F1 & Time for steam process is too long \\
\hline F2 & Operator is neglect \\
\hline F3 & Operator is fatigue \\
\hline F4 & Operator have a little skill and experience \\
\hline F5 & The setting program on the putaran machine is not appropriate \\
\hline F6 & The component of putaran machine is broken \\
\hline F7 & Water condensation has not disappeared \\
\hline F8 & Evaparator machine have a trouble \\
\hline F9 & The machine is broken \\
\hline F10 & The machine is too old \\
\hline F11 & Operator is neglect \\
\hline F12 & There is too much sulfur \\
\hline F13 & Operator is not rigorous \\
\hline F14 & Operator have a poor skill and experience \\
\hline
\end{tabular}

From the results of the model FTA, sugar gravel occurs because one of two failures occur. The failures are the machine in putaran station can not operate well or the results of the masakan process is not good. The machine in the putaran station do not operate well is caused by time for steam process is too long or because the setting of rpm water spray for washing sugar do not appropriate with the condition of sugar which is obtained from the cooking process. The time for steam process is too long is caused by the time setting of sugar dryer is too long, negligence operators, and operator is fatigue when they are working. The setting of improper rpm water spray is caused by operator that less responsive with the problem and there are damage on putaran machine. Operator is not responsive with the machine problem is caused by operator is negligent, operator is being exhausted, or operator have a little skill and experience to operate the putaran machine.

The result of the masakan station is not good can be caused by nira that still contains a lot of water, the machine in the masakan station often do not work, or it can be caused by the thick nira from pemurnian station is too acid. It can cause poor quite quality in masakan station and fragile sugar granules. The thick nira that still contain a lot of water can be caused by the water condensation can not disappear entirely and the evaporator machine always have a problem. The reason of machine in the masakan station often do not work is the machine is broken, the machine is too old, or it can cause by the negligent operator when they are opearting that machine. Meanwhile, the acidic thick nira can cause the addition of sulfur in refinery station is too much, operator do not give the correct amount of sulfur, or because a poor skill and experience of operator. So the operator do not understand the composition of process production material. 


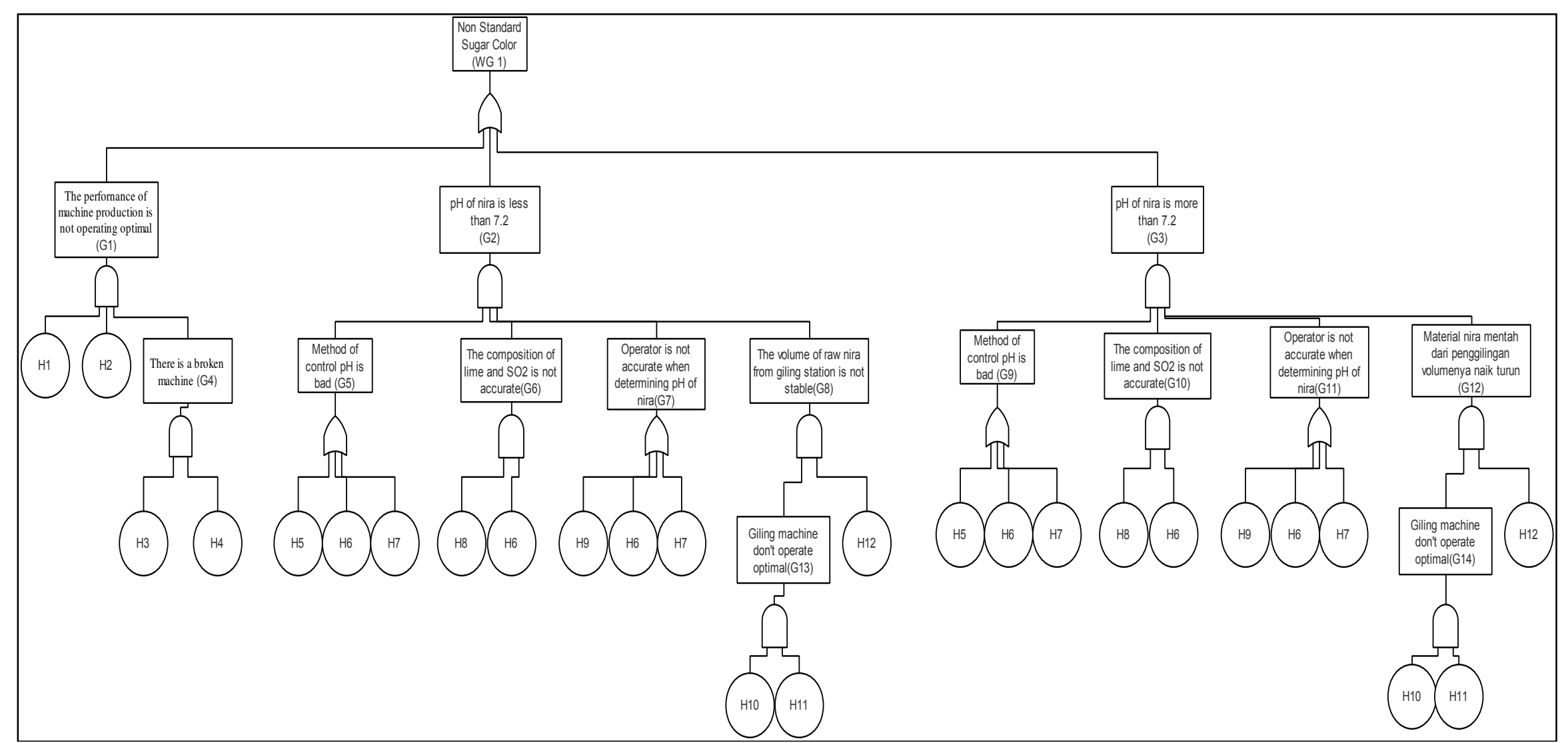

Figure 3. FTA Model for Non Standard Sugar Color 
The following are the symbols'explanation on the basic causes of the FTA model for non standard sugar color:

Table 7. The Symbols' Explanation for Non Standard Sugar Color

\begin{tabular}{|c|l|}
\hline Code & \multicolumn{1}{|c|}{ Explanation } \\
\hline H1 & The machine is too old \\
\hline H2 & The machine has not operated during maintenance time \\
\hline H3 & The result of maintenance activities is bad \\
\hline H4 & There are a machine that do not pass the final test during maintenance time \\
\hline H5 & Operator do not monitor the process well. \\
\hline H6 & Operator is neglect \\
\hline H7 & Operator have a poor skill and experience \\
\hline H8 & Operator is not rigorous \\
\hline H9 & Operator is fatigue \\
\hline H10 & The machine is too old \\
\hline H11 & There are a component of giling machine broken. \\
\hline H12 & Interval time of sugarcane arrival have various time \\
\hline
\end{tabular}

From the results of FTA model, it show that non standard sugar color can occur if one of three major failure occur in the process. That three major failure are the performance of machine is not optimal, the $\mathrm{pH}$ of nira is less then 7.2 and the $\mathrm{pH}$ of nira is more than 7.2. The performance of machine production do not operate optimal because the entire machine production has not operated during maintenance time, the machine is too old, and there are damage in putaran machine. The machine damage canoccure because the result of maintenance activity is bad and there are some machine production that do not pass the final test during maintenance time.

Meanwhile, The $\mathrm{pH}$ of nira less than 7.2 and the $\mathrm{pH}$ of nira more than 7.2 have a similar cause. It can be caused by the method of control $\mathrm{pH}$ is bad, the composition of lime and $\mathrm{SO}_{2}$ is not accurate, operator is not accurate when determining the $\mathrm{pH}$ of nira, and the volume of raw nira from giling station is not stable. The cause of a poor control $\mathrm{pH}$ is operator do not monitor the process well, operator fatigue, or operator have poor skill and experience. The composition of lime and $\mathrm{SO}_{2}$ is not accurate because the operator is not rigorous and neglect. The operator is not accurate when determining $\mathrm{pH}$ of nira can caused by operator is neglect, fatigue, or operator has poor skill and experience. Meanwhile, the volume of raw nira is not stable can caused by giling machine do not operate optimal and interval time of sugarcane arrival have various time. The milling machine do not operate optimal can caused by the component of giling machine has broken and the machine is too old.

Based on the Fault Tree Analysis, the minimal cut set can be determined for each top event. Cut set is a combination of basic event that can cause the top event. Once the cut set is decided then the criticality of failure will known. A cut set with one basic event is more critical than a cut set with two or more basic event. The cut set will determine with MOCUS (Method to Obtain Cut Set) method which is used to get cut set from FTA model. The following is a cut set for wet sugar event 
Table 8.Cut Set

\begin{tabular}{|c|c|c|c|c|c|}
\hline No & $\begin{array}{c}\text { Event } \\
\text { Combination Wet } \\
\text { Sugar }\end{array}$ & No & $\begin{array}{c}\text { Event } \\
\text { Combination } \\
\text { Gravel Sugar } \\
\end{array}$ & No & $\begin{array}{c}\text { Event Combination } \\
\text { Non Standard } \\
\text { Sugar Color } \\
\end{array}$ \\
\hline 1 & B13.B14 & 1 & F1.F2.F3.F4 & 1 & $\mathrm{H} 1 . \mathrm{H} 2 . \mathrm{H} 3 . \mathrm{H} 4$ \\
\hline & & & & 2 & H5.H8.H6.H9.H10. \\
\hline 2 & B15 & 2 & F2.F5 & & H11.H12 \\
\hline & & & & 3 & H6.H8.H6.H10.H11. \\
\hline 3 & $\begin{array}{l}\text { B16 } \\
\text { B1.B2.B3.C1.B4.B }\end{array}$ & 3 & F2.F6 & & $\begin{array}{l}\text { H12 } \\
\text { H7.H8.H6.H10.H11. }\end{array}$ \\
\hline 4 & $\begin{array}{l}\text { 5.B6 } \\
\text { B1.B2.B3.C1.B4.B }\end{array}$ & 4 & F3.F5 & & H12 \\
\hline 5 & $\begin{array}{l}\text { 5.B6.B7 } \\
\text { B1.B2.B3.C1.B4.B }\end{array}$ & 5 & F3.F6 & & \\
\hline 6 & $\begin{array}{l}\text { 5.B6.B5 } \\
\text { B1.B2.B3.C1.B4.B }\end{array}$ & 6 & F4.F5 & & \\
\hline 7 & 5.B6.B8 & 7 & $\begin{array}{l}\text { F4.F6 } \\
\text { F7.F8.F9.F10.F11. }\end{array}$ & & \\
\hline 8 & B9.B10.B11.B12 & $\begin{array}{l}8 \\
9 \\
10\end{array}$ & $\begin{array}{l}\text { F12 } \\
\text { F7.F8.F9.F10.F11. } \\
\text { F13 } \\
\text { F7.F8.F9.F10.F11. } \\
\text { F14 }\end{array}$ & & \\
\hline
\end{tabular}

Based on the table of cut set, there are eight basic event which cause wet sugar event, ten basic event which cause gravel sugar, and four basic event that cause non standard sugar color. In the cut set of wet sugar event, there are two critical event, they are event number 2 (packaging machine is broken) and event number 3 (the quality of sack/plastic pack is bad). But in the cut set of gravel sugar and non standard sugar color, there are not critical event because the minimal combination of basic event is more than one.

\section{Improve Phase}

Improve phase is the fourth step in the six sigma DMAIC. In the improve phase, the recommendations for improvement are determined to the failure modes with FMEA method. The following FMEA table has been obtained from interview and discussion with two experts in KB 1 PT. PG. KrebetBaru, they are Mr. EdyKismanto as supervisor in manufacturing KB 1 and Mr. Sujarwo as supervisor in putaran station KB 1. 
Table 9. FMEA Form for Sugar Cristal Production Process in PT. PG. KrebetBaru KB 1

\begin{tabular}{|c|c|c|c|c|c|c|c|c|c|}
\hline $\begin{array}{l}\text { Types } \\
\text { of } \\
\text { Product } \\
\text { Defect }\end{array}$ & $\begin{array}{l}\text { Processes or } \\
\text { component } \\
\text { that involved }\end{array}$ & Failure Mode & $\begin{array}{l}\text { Potential } \quad \text { Failure } \\
\text { Effects }\end{array}$ & $S$ & Potential Causes & $O$ & Current Controls & $D$ & $\begin{array}{l}\mathbf{R} \\
\mathbf{P} \\
\mathbf{N}\end{array}$ \\
\hline \multirow[t]{4}{*}{$\begin{array}{l}\text { Wet } \\
\text { sugar }\end{array}$} & $\begin{array}{l}\text { Puteran } \\
\text { Process }\end{array}$ & $\begin{array}{l}\text { Performance } \\
\text { machine do not } \\
\text { operate optimal in } \\
\text { the beginning of } \\
\text { process. }\end{array}$ & $\begin{array}{l}\text { The bad sugar product } \\
\text { will occur, as wet sugar }\end{array}$ & 8 & $\begin{array}{l}\text { There are dust and dirt in the } \\
\text { machine that operate in the } \\
\text { beginning of sugar process } \\
\text { period. So the condition of } \\
\text { machine has not stable }\end{array}$ & 3 & $\begin{array}{l}\text { Run the simulation of } \\
\text { sugar production process } \\
\text { using water. }\end{array}$ & 3 & 72 \\
\hline & & $\begin{array}{l}\text { The dryer } \\
\text { temperature is less } \\
\text { than it should. }\end{array}$ & $\begin{array}{l}\text { Sugar still contain a } \\
\text { water. }\end{array}$ & 6 & $\begin{array}{l}\text { The machine production is } \\
\text { too old, operator negligent, } \\
\text { the process of evaporation in } \\
\text { ketel station is not optimal, }\end{array}$ & 3 & $\begin{array}{l}\text { Check the temperature } \\
\text { and preasure of steam in } \\
\text { the steam pipe or dryer } \\
\text { with thermometer and } \\
\text { nanometer. }\end{array}$ & 4 & 72 \\
\hline & $\begin{array}{l}\text { Sugar } \\
\text { warehouse }\end{array}$ & $\begin{array}{l}\text { Sugar packing is } \\
\text { bad }\end{array}$ & $\begin{array}{l}\text { The sugar will contact } \\
\text { with air when it is stored } \\
\text { in thewarehouse. So the } \\
\text { microba can grow and } \\
\text { make the sugar wet. }\end{array}$ & 5 & $\begin{array}{l}\text { Packing machine is not pack } \\
\text { the sugar well. It also caused } \\
\text { by operator negligence. }\end{array}$ & 4 & $\begin{array}{l}\text { Check the sack/plastic } \\
\text { pack of sugar before it } \\
\text { store in the warehouse. }\end{array}$ & 3 & 60 \\
\hline & & $\begin{array}{l}\text { The sugar } \\
\text { warehouse is not } \\
\text { apply the standard } \\
\text { procedure to handle } \\
\text { the sugar }\end{array}$ & $\begin{array}{l}\text { The sugar will become } \\
\text { wet. }\end{array}$ & 4 & $\begin{array}{l}\text { The arrangement of sacks of } \\
\text { sugar in the ware house is } \\
\text { not close with the other } \\
\text { sack. }\end{array}$ & 3 & $\begin{array}{l}\text { Check the condition of } \\
\text { sack of sugar. }\end{array}$ & 5 & 60 \\
\hline \multirow[t]{2}{*}{$\begin{array}{l}\text { Gravel } \\
\text { Sugar }\end{array}$} & $\begin{array}{l}\text { Puteran } \\
\text { process }\end{array}$ & $\begin{array}{l}\text { The time for steam } \\
\text { process is too long }\end{array}$ & $\begin{array}{l}\text { The sugar become very } \\
\text { sticky and hard. }\end{array}$ & 7 & $\begin{array}{l}\text { The setting time for steam } \\
\text { process is too long. }\end{array}$ & 6 & $\begin{array}{l}\text { Check the result of } \\
\text { putaran process in the } \\
\text { shaking gutter. }\end{array}$ & 5 & 210 \\
\hline & & $\begin{array}{l}\text { The setting of rpm } \\
\text { water spray is not } \\
\text { appropriate with } \\
\text { the condition of } \\
\text { sugar. }\end{array}$ & $\begin{array}{l}\text { The shape of sugar } \\
\text { become a gravel. }\end{array}$ & 8 & $\begin{array}{l}\text { The water spray is less then } \\
\text { it should and it also caused } \\
\text { by the operator negligent. }\end{array}$ & 3 & $\begin{array}{l}\text { Check the sugar in the } \\
\text { putaran station with } \\
\text { sampling method. }\end{array}$ & 3 & 72 \\
\hline
\end{tabular}


Table 9. FMEA Form for Sugar Cristal Production Process in PT. PG. KrebetBaru KB 1

\begin{tabular}{|c|c|c|c|c|c|c|c|c|c|}
\hline $\begin{array}{l}\text { Types } \\
\text { of } \\
\text { Product } \\
\text { Defect }\end{array}$ & $\begin{array}{l}\text { Processes or } \\
\text { component } \\
\text { that involved }\end{array}$ & Failure Mode & $\begin{array}{l}\text { Potential Failure } \\
\text { Effects }\end{array}$ & $S$ & Potential Causes & $O$ & Current Controls & $D$ & $\begin{array}{l}\mathbf{R} \\
\mathbf{P} \\
\mathbf{N}\end{array}$ \\
\hline & $\begin{array}{l}\text { Masakan } \\
\text { Process }\end{array}$ & $\begin{array}{l}\text { The quality of quite } \\
\text { from masakan } \\
\text { process is poor. }\end{array}$ & $\begin{array}{l}\text { Soft granule of crystal } \\
\text { sugar will close the } \\
\text { sieve in putaran } \\
\text { machine, so that sugar } \\
\text { can not separate with } \\
\text { the syrup and it will } \\
\text { become clot. }\end{array}$ & 7 & $\begin{array}{l}\text {-Poor quality of sugar seed, } \\
\text { machine masakan often } \\
\text { have problem, and the nira } \\
\text { still contain a water.. }\end{array}$ & 4 & $\begin{array}{l}\text { Check the sugar in } \\
\text { masakan station with } \\
\text { sampling method. }\end{array}$ & 3 & 84 \\
\hline $\begin{array}{l}\text { Non } \\
\text { standard } \\
\text { sugar } \\
\text { color }\end{array}$ & $\begin{array}{l}\text { Pemurnian } \\
\text { process }\end{array}$ & $\begin{array}{l}\text { Performance } \\
\text { machine do not } \\
\text { operate optimal in } \\
\text { the beginning of } \\
\text { process. }\end{array}$ & $\begin{array}{l}\text { The bad sugar } \\
\text { product will occur, as } \\
\text { non standard sugar } \\
\text { color. }\end{array}$ & 8 & $\begin{array}{l}\text { There are dust and dirt in the } \\
\text { machine that operate in the } \\
\text { beginning of sugar process } \\
\text { period. So the condition of } \\
\text { machine has not stable }\end{array}$ & 4 & $\begin{array}{l}\text { Run the simulation of } \\
\text { sugar production } \\
\text { process using water. }\end{array}$ & 3 & 96 \\
\hline & & $\begin{array}{l}\mathrm{pH} \text { of nira is more } \\
\text { than } 7.2\end{array}$ & $\begin{array}{l}\text { The sugar color } \\
\text { (ICUMSA) is too } \\
\text { white and the nira is } \\
\text { too base, so the sugar } \\
\text { will become dark } \\
\text { gradually. }\end{array}$ & 6 & $\begin{array}{l}\text { The composition of support } \\
\text { materials is not accurate. }\end{array}$ & 8 & $\begin{array}{l}\text { Check the } \mathrm{pH} \text { of nira in } \\
\text { the pemurnian station } \\
\text { with pH test paper. }\end{array}$ & 3 & 144 \\
\hline & & $\begin{array}{l}\mathrm{pH} \text { of nira is less } \\
\text { than } 7.2\end{array}$ & $\begin{array}{l}\text { The color of sugar } \\
\text { become darker and } \\
\text { the nira is to acid. }\end{array}$ & 5 & $\begin{array}{l}\text { The nira still contain many } \\
\text { molasses and the } \\
\text { composition of support } \\
\text { materials is not accurate. }\end{array}$ & 7 & $\begin{array}{l}\text { Check the } \mathrm{pH} \text { of nira in } \\
\text { the pemurnian station } \\
\text { with pH test paper. }\end{array}$ & 3 & 105 \\
\hline
\end{tabular}


From the result of FMEA, the next step is sorting the values of RPN that have been obtained. The RPN values will be sorted from largest to smallest. Here is the table of sorting the RPN values:

Table 10. Sorting The RPN Value

\begin{tabular}{|c|c|c|c|c|c|c|}
\hline $\begin{array}{l}\text { Types of } \\
\text { Product Defect }\end{array}$ & Failure Mode & $\mathbf{S}$ & $\mathbf{O}$ & D & RPN & Rank \\
\hline Gravel sugar & The time for steam process is too long & 7 & 6 & 5 & 210 & 1 \\
\hline $\begin{array}{l}\text { Non standard } \\
\text { sugar color }\end{array}$ & $\mathrm{pH}$ of nira is more than 7.2 & 6 & 8 & 3 & 144 & 2 \\
\hline $\begin{array}{l}\text { Non standard } \\
\text { sugar color }\end{array}$ & $\mathrm{pH}$ of nira is less than 7.2 & 5 & 7 & 3 & 105 & 3 \\
\hline $\begin{array}{l}\text { Non standard } \\
\text { sugar color }\end{array}$ & $\begin{array}{l}\text { Performance machine do not operate optimal } \\
\text { in the beginning of process. }\end{array}$ & 8 & 4 & 3 & 96 & 4 \\
\hline Gravel sugar & $\begin{array}{l}\text { The quality of quite from masakan process is } \\
\text { poor. }\end{array}$ & 7 & 4 & 3 & 84 & 5 \\
\hline Gravel sugar & $\begin{array}{l}\text { The setting of rpm water spray is not } \\
\text { appropriate with the condition of sugar. }\end{array}$ & 8 & 3 & 3 & 72 & 6 \\
\hline Wet sugar & $\begin{array}{l}\text { Performance machine do not operate optimal } \\
\text { in the beginning of process. }\end{array}$ & 8 & 3 & 3 & 72 & 7 \\
\hline Wet sugar & The dryer temperature is less than it should. & 6 & 4 & 3 & 72 & 8 \\
\hline Wet sugar & Sugar packing is bad & 5 & 4 & 3 & 60 & 9 \\
\hline Wet sugar & $\begin{array}{l}\text { The sugar warehouse is not apply the } \\
\text { standard procedure to handle the sugar }\end{array}$ & 4 & 3 & 5 & 60 & 10 \\
\hline
\end{tabular}

Based on the sorting the RPN values, it can be known which failure moda that need an action recommended to improve the quality of sugar production process. The action recommended arebase on the result of analysis with FTA and FMEA. So it can fix the real problem in the process production. This action has been recommended by the experts who know the sugar production process well. The experts are Mr Edi Kismanto as supervisor manufacturing KB1 and MrSujarwo as supervisor in putaran station $\mathrm{KB} 1$. Here is the table of action recommended:

Table 11. Action Recommended

\begin{tabular}{|l|l|l|l|l|}
\hline $\begin{array}{l}\text { Types of } \\
\text { Product Defect }\end{array}$ & Failure Mode & RPN & Rank & Action Recommended \\
\hline Gravel Sugar & $\begin{array}{l}\text { The time for } \\
\text { steam process } \\
\text { is too long }\end{array}$ & 210 & 1 & $\begin{array}{l}\text {-Installing a sensor for detect the } \\
\text { moisture content of sugar before it is } \\
\text { entering the steam process, so that the } \\
\text { machine or operator can determine the } \\
\text { accurate time for drying sugar. } \\
\text {-The operator have to get training before } \\
\text { operate the production process. }\end{array}$ \\
\hline $\begin{array}{l}\text { Non standard } \\
\text { sugar color }\end{array}$ & $\begin{array}{l}\text { pH of nira is } \\
\text { more than 7.2 }\end{array}$ & 144 & 2 & $\begin{array}{l}\text {-Maximizing the coordination among } \\
\text { operators. } \\
\text {-Installing an automatic pH control to } \\
\text { monitor the ph of nira. The indicator } \\
\text { tube of automatic ph control is inserted } \\
\text { in the sample container, then it will give } \\
\text { a signal when the pH of nira more than } \\
\text { 7.2. }\end{array}$ \\
\hline
\end{tabular}


Table 11. Action Recommended

\begin{tabular}{|c|c|c|c|c|}
\hline $\begin{array}{l}\text { Types of } \\
\text { Product } \\
\text { Defect }\end{array}$ & Failure Mode & RPN & Rank & Action Recommended \\
\hline $\begin{array}{l}\text { Non } \\
\text { standard } \\
\text { sugar color }\end{array}$ & $\begin{array}{l}\mathrm{pH} \text { of nira is less } \\
\text { than } 7.2\end{array}$ & 105 & 3 & $\begin{array}{l}\text {-The supervisor have to active in check } \\
\text { the condition of the pemurnian process. } \\
\text { - Installing an automatic pH control to } \\
\text { monitor the ph of nira. The indicator tube } \\
\text { of automatic ph control is inserted in the } \\
\text { sample container, then it will give a } \\
\text { signal when the pH of nira less than } 7.2 \text {. }\end{array}$ \\
\hline $\begin{array}{l}\text { Non } \\
\text { standard } \\
\text { sugar color }\end{array}$ & $\begin{array}{l}\text { Performance } \\
\text { machine do not } \\
\text { operate optimal in } \\
\text { the beginning of } \\
\text { process. }\end{array}$ & 96 & 4 & $\begin{array}{l}\text {-Maximizing the maintenance in juice } \\
\text { heater machine, so that it can realese a } \\
\text { optimal heat to optimize the } \\
\text { sedimentation process. } \\
\text {-Maximizing the maintenance in } \\
\text { sedimentation vessel and sulfitasi vessel, } \\
\text { so that the crust in that vessel cannot } \\
\text { affect the pH of nira. } \\
\text {-The company have to improve the } \\
\text { quality of human resources and the } \\
\text { quality of the operator training. }\end{array}$ \\
\hline $\begin{array}{l}\text { Gravel } \\
\text { sugar }\end{array}$ & $\begin{array}{l}\text { The quality of } \\
\text { quite from } \\
\text { masakan process is } \\
\text { poor. }\end{array}$ & 84 & 5 & $\begin{array}{l}\text {-Installing a separator (blower) which is } \\
\text { placed between the masakan station and } \\
\text { puteran station, so that the crystal size of } \\
\text { sugar that entry the putaran station is } \\
\text { between } 0.8-1 \mathrm{~mm} \text {. }\end{array}$ \\
\hline $\begin{array}{l}\text { Gravel } \\
\text { sugar }\end{array}$ & $\begin{array}{l}\text { The setting of rpm } \\
\text { water spray is not } \\
\text { appropriate with } \\
\text { the condition of } \\
\text { sugar. }\end{array}$ & 72 & 6 & $\begin{array}{l}\text {-Installing the sensor to dectect } \\
\text { temperature of sugar from masakan } \\
\text { station, so that the operator or machine } \\
\text { can set accurate rpm of watering spray. }\end{array}$ \\
\hline Wet sugar & $\begin{array}{l}\text { Performance } \\
\text { machine do not } \\
\text { operate optimal in } \\
\text { the beginning of } \\
\text { process. }\end{array}$ & 72 & 7 & $\begin{array}{l}\text {-Maximaizing the maintenance in the } \\
\text { evaporator and boiler machine, so that the } \\
\text { machine can achieve the optimal heat } \\
120^{\circ} \mathrm{C} \text {. } \\
\text { - The company have to improve the } \\
\text { quality of human resources and the } \\
\text { quality of the operator training. }\end{array}$ \\
\hline Wet sugar & $\begin{array}{l}\text { The dryer } \\
\text { temperature is less } \\
\text { than it should. }\end{array}$ & 72 & 8 & $\begin{array}{l}\text {-Installing a sensor to give a signal when } \\
\text { the temperature of dryer below the } \\
\text { standard. }\end{array}$ \\
\hline Wet sugar & $\begin{array}{l}\text { Sugar packing is } \\
\text { bad }\end{array}$ & 60 & 9 & $\begin{array}{l}\text {-Installing a sensor to detect non perfect } \\
\text { sugar pack on the conveyor, so that sugar } \\
\text { pack can removed from the conveyor } \\
\text { track. }\end{array}$ \\
\hline Wet sugar & $\begin{array}{l}\text { The sugar } \\
\text { warehouse is not } \\
\text { apply the standard } \\
\text { procedure to } \\
\text { handle the sugar }\end{array}$ & 60 & 10 & $\begin{array}{l}\text {-Sack of sugar must be arranged } \\
\text { accordance with standard procedure } \\
\text { operation. It is arranged from the edge of } \\
\text { wall with a distance } 0.5-1 \mathrm{~m} \text { and } \\
\text { transverse each other. }\end{array}$ \\
\hline
\end{tabular}




\section{E. Control Phase}

Phase control is fifth step of six sigma DMAIC method. At this control phase, the rating of severity, occurance, and detection will be prediticted when the action recommended have already done. So that the new Risk Priority Number (RPN) value can be obtained. The prediction of severity, occurance, and detection is done by Mr. Edi Kismanto as supervisor in manufacturing KB1 and Mr. Sujarwo as supervisor in puteran station KB1. Here's a table of predicted values of severity, occurance, and detection:

Table 12. Predicted Values of severity, Occurance, and Detection

\begin{tabular}{|c|c|c|c|c|c|c|c|c|}
\hline $\begin{array}{c}\text { Types } \\
\text { of } \\
\text { product } \\
\text { defect }\end{array}$ & $\begin{array}{c}\text { Failure } \\
\text { Mode }\end{array}$ & RPN & Rank & $\begin{array}{c}\text { Action } \\
\text { Recommeded }\end{array}$ & $\mathbf{S}$ & 0 & D & RPN \\
\hline $\begin{array}{l}\text { Gravel } \\
\text { sugar }\end{array}$ & $\begin{array}{l}\text { The time } \\
\text { for steam } \\
\text { process is } \\
\text { too long }\end{array}$ & 210 & 1 & $\begin{array}{l}\text {-Installing a sensor for detect the } \\
\text { moisture content of sugar before it } \\
\text { is entering the steam process, so } \\
\text { that the machine or operator can } \\
\text { determine the accurate time for } \\
\text { drying sugar. } \\
\text {-The operator have to get training } \\
\text { before operate the production } \\
\text { process. }\end{array}$ & 4 & 2 & 2 & 16 \\
\hline $\begin{array}{l}\text { Non } \\
\text { standard } \\
\text { sugar } \\
\text { color }\end{array}$ & $\begin{array}{l}\mathrm{pH} \text { of nira } \\
\text { is more } \\
\text { than } 7.2\end{array}$ & 144 & 2 & $\begin{array}{l}\text {-Maximizing the coordination } \\
\text { among operators. } \\
\text {-Installing an automatic } \mathrm{pH} \text { control } \\
\text { to monitor the ph of nira. The } \\
\text { indicator tube of automatic ph } \\
\text { control is inserted in the sample } \\
\text { container, then it will give a signal } \\
\text { when the pH of nira more than } 7.2 \text {. }\end{array}$ & 2 & 4 & 2 & 16 \\
\hline $\begin{array}{l}\text { Non } \\
\text { standard } \\
\text { sugar } \\
\text { color }\end{array}$ & $\begin{array}{l}\text { pH of nira } \\
\text { is less } \\
\text { than } 7.2\end{array}$ & 105 & 3 & $\begin{array}{l}\text {-The supervisor have to active in } \\
\text { check the condition of the } \\
\text { pemurnian process. } \\
\text { - Installing an automatic pH control } \\
\text { to monitor the ph of nira. The } \\
\text { indicator tube of automatic ph } \\
\text { control is inserted in the sample } \\
\text { container, then it will give a signal } \\
\text { when the pH of nira less than } 7.2 \text {. }\end{array}$ & 2 & 5 & 2 & 20 \\
\hline $\begin{array}{l}\text { Non } \\
\text { standard } \\
\text { sugar } \\
\text { color }\end{array}$ & $\begin{array}{l}\text { Performa } \\
\text { nce } \\
\text { machine } \\
\text { do not } \\
\text { operate } \\
\text { optimal in } \\
\text { the } \\
\text { beginning } \\
\text { of } \\
\text { process. }\end{array}$ & 96 & 4 & $\begin{array}{l}\text {-Maximizing the maintenance in } \\
\text { juice heater machine, so that it can } \\
\text { realese a optimal heat to optimize } \\
\text { the sedimentation process. } \\
\text {-Maximizing the maintenance in } \\
\text { sedimentation vessel and sulfitasi } \\
\text { vessel, so that the crust in that } \\
\text { vessel cannot affect the pH of nira. } \\
\text {-The company have to improve the } \\
\text { quality of human resources and the } \\
\text { quality of the operator training. }\end{array}$ & 4 & 2 & 1 & 8 \\
\hline
\end{tabular}




\begin{tabular}{|l|l|l|l|l|l|l|l|l|}
\hline Gravel & $\begin{array}{l}\text { The } \\
\text { Sugality of } \\
\text { quite } \\
\text { from } \\
\text { masakan } \\
\text { process is } \\
\text { poor. }\end{array}$ & 84 & 5 & $\begin{array}{l}\text {-Installing a separator (blower) } \\
\text { which is placed between the } \\
\text { masakan station and puteran } \\
\text { station, so that the crystal size of } \\
\text { sugar that entry the putaran station } \\
\text { is between } 0.8-1 \mathrm{~mm} .\end{array}$ & 2 & 2 & 16 \\
\hline
\end{tabular}

Table 12. Predicted Values of severity, Occurance, and Detection

\begin{tabular}{|c|c|c|c|c|c|c|c|c|}
\hline $\begin{array}{c}\text { Types of } \\
\text { product } \\
\text { defect }\end{array}$ & Failure Mode & RPN & Rank & $\begin{array}{c}\text { Action } \\
\text { Recommeded }\end{array}$ & $\mathbf{S}$ & $\mathbf{O}$ & D & RPN \\
\hline $\begin{array}{l}\text { Gravel } \\
\text { Sugar }\end{array}$ & $\begin{array}{l}\text { The setting of } \\
\text { rpm water } \\
\text { spray is not } \\
\text { appropriate } \\
\text { with the } \\
\text { condition of } \\
\text { sugar. }\end{array}$ & 72 & 6 & $\begin{array}{l}\text {-Installing the sensor to } \\
\text { dectect temperature of } \\
\text { sugar from masakan } \\
\text { station, so that the operator } \\
\text { or machine can set accurate } \\
\text { rpm of watering spray. }\end{array}$ & 1 & 2 & 2 & 4 \\
\hline $\begin{array}{l}\text { Wet } \\
\text { sugar }\end{array}$ & $\begin{array}{l}\text { Performance } \\
\text { machine do not } \\
\text { operate optimal } \\
\text { in the } \\
\text { beginning of } \\
\text { process. }\end{array}$ & 72 & 7 & $\begin{array}{l}\text {-Maximaizing the } \\
\text { maintenance in the } \\
\text { evaporator and boiler } \\
\text { machine, so that the } \\
\text { machine can achieve the } \\
\text { optimal heat } 120^{\circ} \mathrm{C} \text {. } \\
\text { - The company have to } \\
\text { improve the quality of } \\
\text { human resources and the } \\
\text { quality of the operator } \\
\text { training. }\end{array}$ & 4 & 2 & 1 & 8 \\
\hline $\begin{array}{l}\text { Wet } \\
\text { sugar }\end{array}$ & $\begin{array}{l}\text { The dryer } \\
\text { temperature is } \\
\text { less than it } \\
\text { should. }\end{array}$ & 72 & 8 & $\begin{array}{l}\text {-Installing a sensor to give } \\
\text { a signal when the } \\
\text { temperature of dryer below } \\
\text { the standard. }\end{array}$ & 3 & 1 & 1 & 3 \\
\hline $\begin{array}{l}\text { Wet } \\
\text { sugar }\end{array}$ & $\begin{array}{l}\text { Sugar packing } \\
\text { is bad }\end{array}$ & 60 & 9 & $\begin{array}{l}\text {-Installing a sensor to } \\
\text { detect non perfect sugar } \\
\text { pack on the conveyor, so } \\
\text { that sugar pack can } \\
\text { removed from the conveyor } \\
\text { track. }\end{array}$ & 3 & 1 & 1 & 3 \\
\hline $\begin{array}{l}\text { Wet } \\
\text { sugar }\end{array}$ & $\begin{array}{l}\text { The sugar } \\
\text { warehouse is } \\
\text { not apply the } \\
\text { standard } \\
\text { procedure to } \\
\text { handle the } \\
\text { sugar }\end{array}$ & 60 & 10 & $\begin{array}{l}\text {-Sack of sugar must be } \\
\text { arranged accordance with } \\
\text { standard procedure } \\
\text { operation. It is arranged } \\
\text { from the edge of wall with } \\
\text { a distance } 0.5-1 \mathrm{~m} \text { and } \\
\text { transverse each other. }\end{array}$ & 3 & 2 & 2 & 12 \\
\hline
\end{tabular}

From the table of predicted value, it can be known that the RPN of failure moda of the time for steam process is too long has decreased. The RPN value 210 down to 16 when action recommended is performed. According to the experxt opinion, that 
action recommendation can minimize the occurance of gravel sugar because the sensor can detect the moisture content in sugar before it entry to steam process.

\section{CONCLUSION AND RECOMMENDATION}

\section{A. Conclusion}

From this research, it can be concluded that the baseline performance of sugar production process in PT. PG. KrebetBaru is quite good. It is known from the calculation of value sigma on the measure phase. The value sigma of process production in PT.PG.KrebetBaru is 3.58. By using Fault Tree Analysis (FTA) method on the analyze phase, it can be known that the causes of the occurance of gravel sugar, wet sugar, and non standard sugar color is human factor and machine factor. By using Failure Mode and Effect Analysis (FMEA) method, it can be concluded that the priority failure mode with highest RPN 210 is need improvements. The action recommended that should be given is installing a sensor to detect the moisture content in sugar before it entry to steam process and The operator have to get training before operate the production process. Thereby the amount of product defects can be minimized.

\section{B. Recommendation}

There are some recommendation which can be given for future research. First, the control phase just use a predictable result. So for the future research with the same content can do the real implementation to see whether it really can fix the problem. Second, before filled the Failure Mode Affect Analysis (FMEA) form, it need to give simple explanation simple. So that the people in the factory can understand the purpose of research.

\section{REFERENCES}

[1] Evans, J.R. and Lindsay, W.M., 2008, The Management and Control of Quality, Eight Edition, Thomson South-Western, Canada.

[2] Gaspersz, V. 2005. Total Quality Management, PT. Gramedia Pustaka Utama, Jakarta.

[3] Gazpersz, V. 2006. Continous Cost Reduction Through Lean Six Sigma Approach. PT. Gramedia Pustaka Utama, Jakarta.

[4] Goetsch, D.L. dan Davis, S. 2006. Quality Management: Introduction to Total Quality Management for Production, Processing, and Service, Fourth Edition, Pearson Education Inc, New Jersey.

[5] Mulia, T.G. 2011. Implementasi Sistem Manajemen Mutu ISO 9001:2008 Pada Perusahaan JasaKonstruksi, Skripsi S1, Fakultas Teknik Universitas Atmajaya, Yogyakarta.

[6] Nugroho, W.P.S, Pudjotomo, D., danTifani, T.K. 2011. Analisa Penyebab Penurunan Daya Saing Produk Susu Sapi dalam Negeri Terhadap Susu Sapi imporpada industry pengolahan Susu (IPS) dengan Metode Fault Tree Analysis (FTA) dan Barrier Analysis, Jurnal TI UNDIP, 6 (2), hal. 71-80.

[7] Reliability, E.H. 2002. Failure Tree Handbook with Aerospace Applications. SA Office of Safety and Mission Assurance, Washington.

[8] Tjiptono, F. 2000. Manajemen Jasa, Edisipertama, Andi Offset, Yogyakarta.

[9] Vesely, W. 2002. Fault Tree Handbook with Aerospace Applications. SA Office of Safety and Mission Assurance, Washington.

[10] Villacourt, M. 1992. Failure Mode and Effect Analysis (FMEA): A Guide for Continous Improvement for the Semiconductor Equipment Industry. International SEMATECH, Inc. Tersedia di: www. fmea.com (Diakses: 10 Desember 2014). 